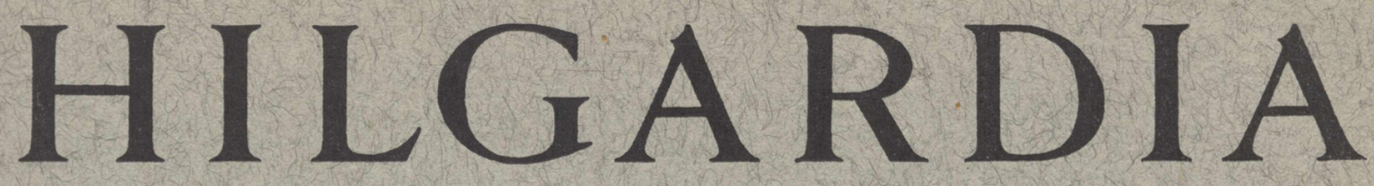

A Journal of Agricultural Science Published by

the California Agricultural Experiment Station

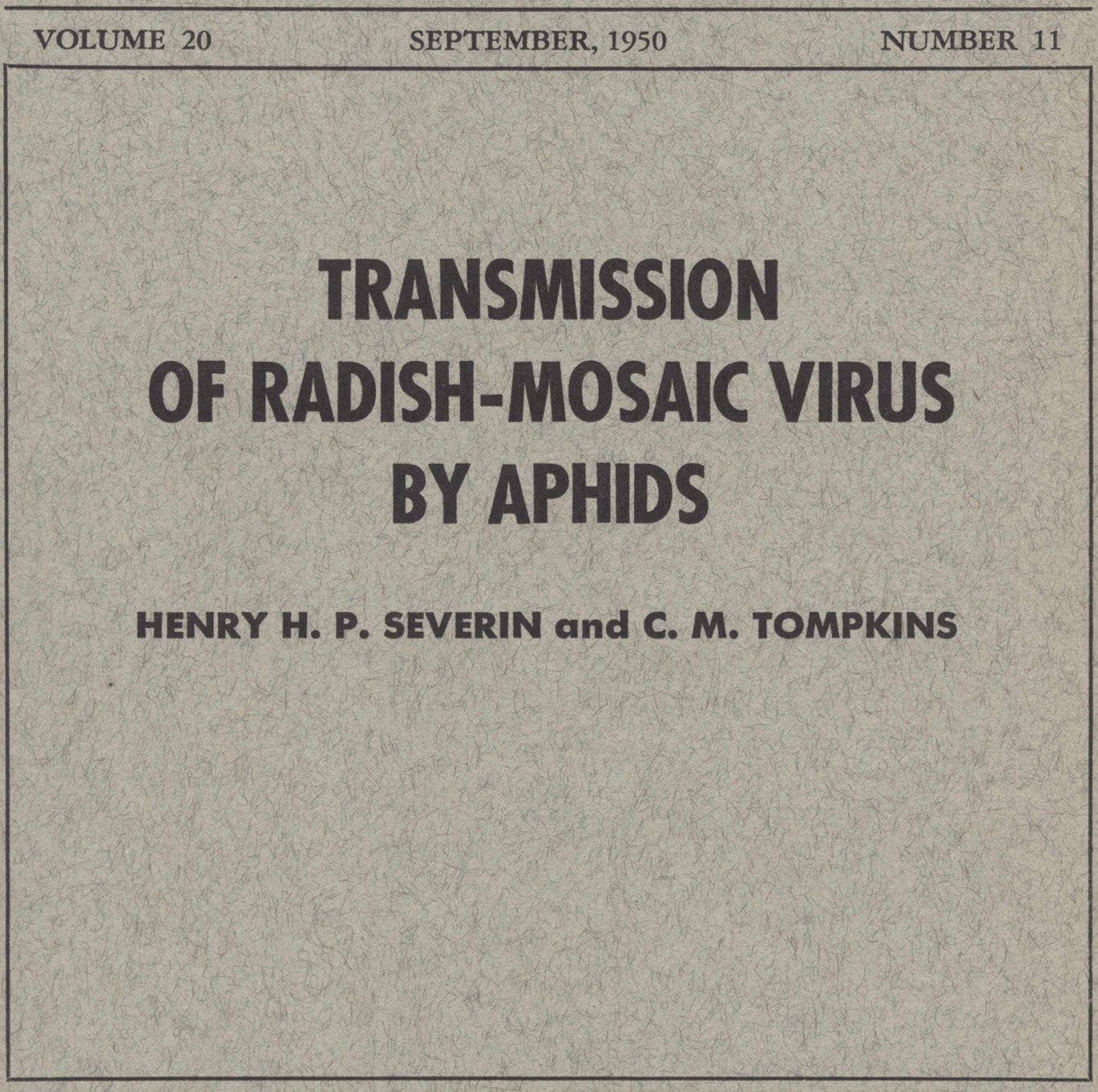

UNIVERSITY OF CALIFORNIA - BERKELEY, CALIFORNIA 


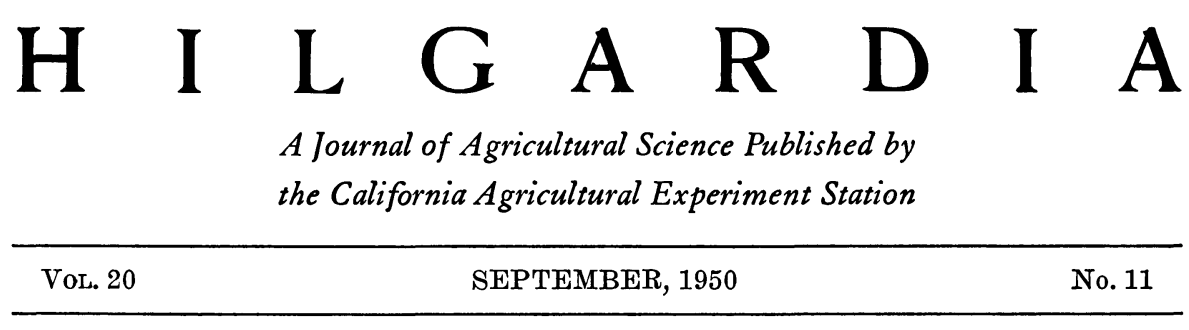

\title{
TRANSMISSION OF RADISH-MOSAIC VIRUS BY APHIDS ${ }^{1}$
}

\author{
HENRY H. P. SEVERIN ${ }^{2}$ and C. M. TOMPKINS ${ }^{3}$
}

\section{INTRODUCTION}

A MOSAIC DISEASE of the cultivated radish (Raphanus sativus) is common in the vegetable gardens of the San Francisco Bay districts. The disease also occurs on wild radish, which probably serves as a reservoir of the virus.

Tompkins (1939) ${ }^{4}$ reviewed the literature on mosaic diseases of Raphanus species. He also published the results of studies on host range and properties of the radish-mosaic virus. The virus was found to be readily transmitted by mechanical inoculation. Numerous unsuccessful attempts were made to transmit the virus by means of the cabbage aphid, Brevicoryne brassicae (L.), turnip or false cabbage aphid, Rhopalosiphum pseudobrassicae (Davis), and the green peach aphid, Myzus persicae (Sulzer).

Magistad (1938) listed daikon (Raphanus sp.) mosaic in the Hawaiian Islands.

Parris (1940) listed a mosaic on Raphanus sp. in Hawaii.

Dale (1948) recorded the occurrence of a mosaic disease on three crucifers in Trinidad, British West Indies, one of which was an eastern variety of radish, known locally as moorei and which he suggested may be Raphanus sativus var. hortensis. He found by inoculation tests that the radish ( $R$. sativus) varieties French Breakfast and Burpee's Red Giant appear to be immune to the virus described in his paper. The virus was transmitted by Rhopalosiphum pseudobrassicae (Davis).

The following is a report of a study undertaken on aphid transmission of the radish-mosaic virus described by Tompkins (1939). Tests were made with aphid species that breed on White Icicle radish under natural conditions and with species that have not been reared on this host plant. A comparison was made between transmission of the virus by unfasted infective aphids, and transmission by previously noninfective fasted aphids after short infection-feeding intervals. Other aspects investigated include a comparison of virus transmission, by lots of varying numbers of aphids, with mechanical inoculation; and the retention of the virus.

\footnotetext{
${ }^{1}$ Received for publication August 29, 1949.

2 Entomologist in the Experiment Station, Berkeley.

${ }^{3}$ Associate Plant Pathologist in the Experiment Station, Berkeley.

"See "Literature Cited" for citations referred to in the text by author and date.
} 


\section{MATERIALS AND METHODS}

The virus was obtained from a naturally infected white radish plant grown near San Pablo, Contra Costa County. It was maintained by repeated mechanical inoculation and aphid transmission of the virus to healthy White Icicle radish seedlings. The carborundum method (Rawlins and Tompkins, 1936) was used in mechanical inoculation. White Icicle radish seedlings grown from seeds were used in all experiments reported in this paper.

Colonies of noninfective aphid species have been reared in the greenhouse for a period of 20 years. The methods of collecting, rearing, and transferring aphids, and of producing noninfective aphids, have been described in previous papers (Severin and Freitag, 1938). Another method of obtaining noninfective aphids has been reported by Severin and Tompkins, 1948.

\section{SYMPTOMATOLOGY}

The first symptom of radish mosaic on plants infected with the virus by aphids or mechanical inoculation usually is a clearing of the veins and veinlets (plate 1, $A$ ), first appearing on the outer or intermediate leaves and spreading to the youngest leaves, followed by yellow veinbanding (plate $1, B$ ). The yellow veinbanding of the veinlets then encloses green, slightly raised areas (plate $2, A, B$ ) which later turn yellow (plate $2, C$ ). Sometimes, however, the first symptom consists of small, circular, chlorotic areas (plate $3, A$ ) between and adjacent to the veins. Fusion of these chlorotic areas later occurs (plate $3, B$ ). Within a few days the chlorotic areas become numerous (plate $3, C$ ) and soon replace the normal green tissue with a coarse mottle (plate $3, D$ ) followed by necrosis (plate $4, A$ ). Sometimes yellow veinbanding of the cleared veinlets and small, circular, chlorotic areas occur on the same leaf (plate $4, B$ ). In the later stage of the disease variable mosaic patterns occur, consisting of chlorotic veinbanding (plate $1, C$, plate $6, C$ ), interveinal chlorosis (plate $1, C$, plate $5, A, B)$, marginal chlorosis (plate $1, D$ ), green veinbanding (plate $6, A, B$ ), occasionally slightly raised dark-green or blisterlike areas (plate $2, D$, plate $6, D$ ). The chlorosis gradually spreads until the leaf becomes yellow (plate $5, C, D)$. In the advanced stage of the disease the youngest leaves are dwarfed and curled (plate 7 ).

\section{TRANSMISSION OF VIRUS}

By Vectors that Breed on Radish under Natural Conditions. Four species of aphids which multiply on radish under natural conditions are vectors of the virus. These are:

Cabbage aphid, Brevicoryne brassicae (L.)

Turnip or false cabbage aphid, Rhopalosiphum pseudobrassicae (Davis)

Ornate aphid, Myzus ornatus Laing

Green peach aphid, Myzus persicae (Sulzer)

By Vectors that Do Not Breed on Radish. The following eight species of aphids which do not multiply on radish in the greenhouse are vectors of the virus :

Celery aphid, Aphis apii Theobald

Rusty-banded aphid, Aphis ferruginea-striata Essig

Cotton or melon aphid, Aphis gossypii Glover 
Bean or dock aphid, Aphis rumicis L.

Yellow willow aphid, Cavariella aegopodii (Fabricius)

Pea aphid, Macrosiphum pisi (Kaltenbach)

Lily aphid, Myzus circumflexus (Buckton)

Foxglove aphid, Myzus solani (Kaltenbach)

By Unstarved Single Infective Aphids that Multiply on Radish. Four species of unstarved, infective, single aphids that breed on radish outdoors were tested as vectors of the virus. These, the cabbage, false cabbage or turnip, ornate, and green peach aphids were reared on mosaic-infected radish plants,

TABLE 1

TRANSMISSION OF RADISH-MOSAIC VIRUS BY SPECIES OF UNSTARVED, SINGLE, WINGLESS, INFECTIVE APHIDS FROM DISEASED TO HEALTHY PLANTS

\begin{tabular}{|c|c|c|c|}
\hline Common and scientific names of aphids & $\begin{array}{c}\text { Plants } \\
\text { inoculated }\end{array}$ & $\begin{array}{c}\text { Plants } \\
\text { infected }\end{array}$ & $\begin{array}{l}\text { Per cent } \\
\text { infected }\end{array}$ \\
\hline Celery aphid, A phis apii* ............... & 50 & 1 & 2.0 \\
\hline Rusty banded aphid, Aphis ferruginea-striata. . & 50 & 1 & 2.0 \\
\hline Cotton or melon aphid, Aphis gossypii.......... & 25 & 4 & 8.0 \\
\hline Bean or dock aphid, Aphis rumicis................. & 100 & 2 & 2.0 \\
\hline 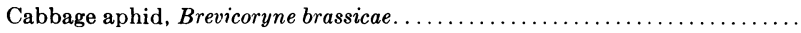 & 25 & 9 & 36.0 \\
\hline Yellow willow aphid, Cavariella aegopcdii............ & 25 & 6 & 24.0 \\
\hline 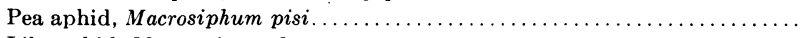 & 25 & 11 & 22.0 \\
\hline Lily aphid, Myzus circumflexus...................... & 50 & 6 & 24.0 \\
\hline Ornate aphid, Myzus ornatus........ & 25 & 10 & 10.0 \\
\hline Green peach aphid, Myzus persicae....... & 100 & 12 & 48.0 \\
\hline Foxglove aphid, Myzus solani............. & 25 & 5 & 20.0 \\
\hline Honeysuckle aphid, Rhopalosiphum conii..... & 25 & 1 & 2.0 \\
\hline Turnip aphid, Rhopalosiphum pseudobrassicae.. & 25 & 3 & 12.0 \\
\hline
\end{tabular}

* According to E. O. Essig (personal interview) A phis apii Theobald may be identical with A. helianthi Monell.

and then each aphid was fed singly on a healthy radish seedling. Table 1 shows that the cabbage aphid infected 36 per cent, the turnip aphid 12 per cent, the ornate aphid 10 per cent, and the green peach aphid 48 per cent of the 25 to 100 plants inoculated with each species.

By Previously Noninfective, Starved, Single Aphids in Short Infectionfeeding Periods. Previously noninfective, starved, wingless aphids were fasted two to three hours in a phial, and then were fed singly on a mosaicinfected radish plant for one-half, one, two, five, or ten minutes, and then on a healthy radish seedling. A comparison of the results obtained in tables 1 and 2 shows that higher percentages of transmission of the virus were obtained with starved single aphids in short infection-feeding periods than with unstarved single aphids, with the exception of the bean or dock, cabbage, yellow willow, and pea aphids. Table 2 shows that the bean or dock and honeysuckle aphids failed to transmit the virus.

\section{COMPARATIVE EFFICIENCY OF MECHANICAL INOCULATION AND APHID TRANSMISSION OF VIRUS}

A comparison was made of mechanical inoculation and aphid transmission of the virus. In each test, a single species of infective wingless aphids was transferred, in lots of 10 and 20, from infected to healthy plants. Thirteen 


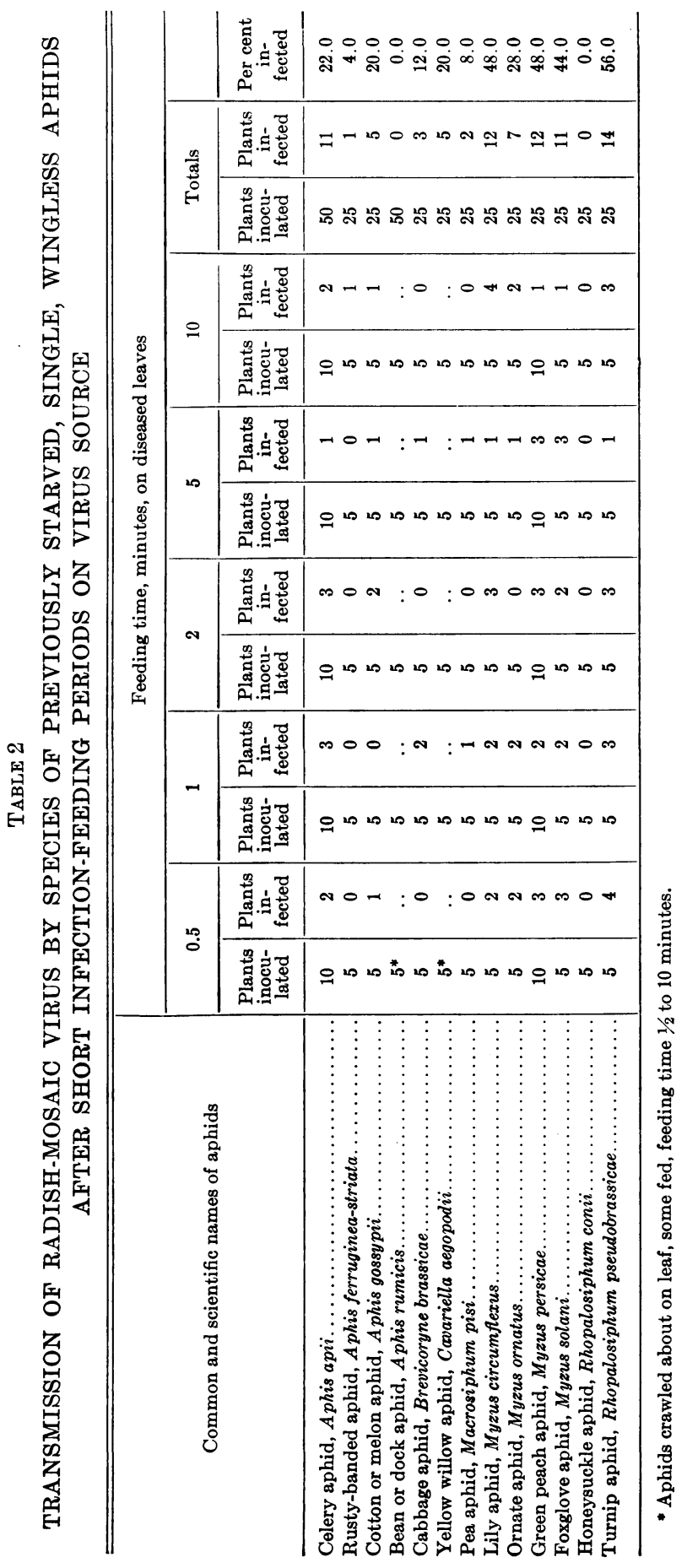


TABLE 3

COMPARISON OF TRANSMISSION OF RADISH-MOSAIC VIRUS BY MECHANICAL INOCULATION WITH SPECIES OF

APHID, 20 IN EACH LOT

\begin{tabular}{|c|c|c|c|c|c|c|c|}
\hline \multicolumn{3}{|c|}{ Mechanical inoculation } & \multicolumn{5}{|c|}{ Aphid transmission } \\
\hline $\begin{array}{l}\text { Plants } \\
\text { inocu- } \\
\text { lated }\end{array}$ & $\begin{array}{c}\text { Plants } \\
\text { infected }\end{array}$ & $\begin{array}{l}\text { Per cent } \\
\text { infected }\end{array}$ & $\begin{array}{l}\text { Common and scientific } \\
\text { names of aphids }\end{array}$ & $\begin{array}{c}\text { Number } \\
\text { of } \\
\text { aphids }\end{array}$ & $\begin{array}{l}\text { Plants } \\
\text { inocu- } \\
\text { lated }\end{array}$ & $\begin{array}{l}\text { Plants } \\
\text { infected }\end{array}$ & $\begin{array}{l}\text { Per cent } \\
\text { infected }\end{array}$ \\
\hline 10 & 3 & 30.0 & Celery aphid, Aphis apii & 10 & 10 & 5 & 50.0 \\
\hline 10 & 10 & 100.0 & & 20 & 10 & 6 & 60.0 \\
\hline 10 & 10 & 100.0 & Rusty-banded aphid, Aphis & 10 & 10 & 4 & 40.0 \\
\hline 10 & 0 & 0.0 & ferruginea-striata & 20 & 10 & 1 & 10.0 \\
\hline 10 & 9 & 90.0 & Cotton or melon aphid, $A p h i s$ & 10 & 10 & 6 & 60.0 \\
\hline 10 & 3 & 30.0 & gossypii & 20 & 10 & 10 & 100.0 \\
\hline 60 & 12 & 20.0 & Bean or dock aphid, Aphis & 10 & 60 & 0 & 0.0 \\
\hline 20 & 7 & 70.0 & rumicis & 20 & 10 & 0 & 0.0 \\
\hline 10 & 9 & 90.0 & Cabbage aphid, Brevicoryne & 10 & 10 & 10 & 100.0 \\
\hline 25 & 20 & 80.0 & brassicae & 20 & 25 & 18 & 72.0 \\
\hline 10 & 8 & 80.0 & Yellow willow aphid, Cavariella & 10 & 10 & 7 & 70.0 \\
\hline 10 & 7 & 70.0 & aegopodii & 20 & 10 & 8 & 80.0 \\
\hline 10 & 10 & 100.0 & Pea aphid, Macrosiphum pisi & 20 & 10 & 9 & 90.0 \\
\hline 10 & 10 & 100.0 & & 10 & 10 & 10 & 100.0 \\
\hline 10 & 5 & 50.0 & Lily aphid, Myzus circumflexus & 10 & 10 & 6 & 60.0 \\
\hline 10 & 8 & 80.0 & & 20 & 10 & 7 & 70.0 \\
\hline 10 & 8 & 80.0 & Ornate aphid, Myzus ornatus & 10 & 10 & 9 & 90.0 \\
\hline 20 & 4 & 20.0 & & 20 & 10 & 2 & 20.0 \\
\hline 10 & 10 & 100.0 & Green peach aphid, Myzus & 10 & 10 & 5 & 50.0 \\
\hline 10 & 8 & 80.0 & persicae & 20 & 10 & 1 & 10.0 \\
\hline 10 & 9 & 90.0 & Foxglove aphid, Myzus solani & 10 & 10 & 2 & 20.0 \\
\hline 10 & 4 & 40.0 & & 20 & 20 & 6 & 30.0 \\
\hline 20 & 16 & 80.0 & Honeysuckle aphid, & 10 & 20 & 0 & 0.0 \\
\hline 20 & 15 & 75.0 & Rhopalosiphum conii & 20 & 20 & 0 & 0.0 \\
\hline 20 & 14 & 70.0 & Turnip aphid, Rhopalosiphum & 10 & 20 & 8 & 40.0 \\
\hline 10 & 4 & 40.0 & pseudobrassicae & 20 & 10 & 8 & 80.0 \\
\hline
\end{tabular}

species were so tested. Also, the virus from the same infected plants upon which the aphids had fed was mechanically inoculated in healthy plants. The results obtained are given in table 3 .

Of 13 species of aphids tested, the pea aphid was the most efficient vector. The bean or dock and honeysuckle aphids failed to transmit the virus. A comparison of the transmission of the virus by lots of 10 aphids with lots of 20 aphids (excepting the two species which failed to infect any of the plants) shows that in the ten-aphid lots a total of 72 of 120 plants, or 56 per cent, were infected; while in the 20 aphid lots 76 of 135 plants, or 60 per cent, were infected. 
Of the 255 plants mechanically inoculated, 173 plants or 68 per cent were infected, omitting the results of mechanical inoculation with the two species which failed to transmit the virus. It is evident that the 11 species of aphids were less efficient than mechanical inoculation in transmitting the virus.

\section{RETENTION OF VIRUS}

By Lots of 20 Aphids in Daily Transfers. Retention of the virus was determined for four species of aphids reared on infected radish plants. Lots of 20 aphids of each species were transferred daily for three days to successive healthy plants. As table 4 shows, each of the four species transmitted the virus from diseased to healthy plants during the first day but none of the lots produced infections during the second and third days.

TABLE 4

RETENTION OF RADISH-MOSAIC VIRUS BY FOUR SPECIES OF APHIDS, 20 IN EACH LOT

\begin{tabular}{|c|c|c|c|c|c|c|c|}
\hline \multirow[b]{2}{*}{ Aphid specie } & \multirow{2}{*}{$\begin{array}{c}\text { Number } \\
\text { of } \\
\text { lots }\end{array}$} & \multicolumn{2}{|c|}{ First day } & \multicolumn{2}{|c|}{ Second day } & \multicolumn{2}{|c|}{ Third day } \\
\hline & & $\begin{array}{l}\text { Plants } \\
\text { inocu- } \\
\text { lated }\end{array}$ & $\begin{array}{l}\text { Plants } \\
\text { in- } \\
\text { fected }\end{array}$ & $\begin{array}{l}\text { Plants } \\
\text { inocu- } \\
\text { lated }\end{array}$ & $\begin{array}{l}\text { Plants } \\
\text { in- } \\
\text { fected }\end{array}$ & $\begin{array}{l}\text { Plants } \\
\text { inocu- } \\
\text { lated }\end{array}$ & $\begin{array}{l}\text { Plants } \\
\text { in- } \\
\text { fected }\end{array}$ \\
\hline $\begin{array}{l}\text { Cabbage aphid, Brevicoryne brassicae. } \\
\text { Turnip aphid, Rhopalosiphum }\end{array}$ & 5 & 5 & 5 & 5 & 0 & 5 & 0 \\
\hline pseudobrassicae............... & 5 & 5 & 5 & 5 & 0 & 5 & 0 \\
\hline Ornate aphid, Myzus ornatus..... & 5 & 5 & 4 & 5 & 0 & 5 & 0 \\
\hline Green peach aphid, Myzus persicae. & 5 & 5 & 3 & 5 & 0 & 5 & 0 \\
\hline
\end{tabular}

By Lots of 20 Aphids with Hourly Transfers. An experiment was conducted to determine more precisely how long aphids of four species would retain the virus. Lots of 20 infective, wingless aphids reared on infected radish plants were transferred hourly to six successive healthy plants.

As table 5 shows, one lot of cabbage aphids infected three successive plants during the first three hours, two lots during the first two hours, and two lots during the first hour only. One lot of turnip aphids produced infections in three successive plants during the first three hours, and four lots during the first two hours. Two lots of ornate aphids infected three successive plants during the first and second hours, and three lots during the first hour only. Three lots of green peach aphids caused infections during the first hour only.

Conclusion. The virus is of the nonpersistent type (Watson, 1939, Watson and Roberts, 1940) in the aphid vectors, and was retained from one to three hours. According to Tompkins (1939) the virus remained active in vitro for 14 days at $22^{\circ} \mathrm{C}$, but was inactivated after 16 days. 
TABLE 5

RETENTION OF RADISH-MOSAIC VIRUS BY FOUR SPECIES OF APHIDS TRANSFERRED HOURLY TO SIX SUCCESSIVE HEALTHY PLANTS

\begin{tabular}{|c|c|c|c|c|c|c|c|c|}
\hline \multirow{2}{*}{ Aphid species and lot no. } & \multirow{2}{*}{$\begin{array}{c}\text { Number } \\
\text { of } \\
\text { aphids } \\
\text { on first } \\
\text { plant }\end{array}$} & \multicolumn{6}{|c|}{$\begin{array}{l}\text { Results* on successive plants, } \\
\text { with hourly transfers }\end{array}$} & \multirow{2}{*}{$\begin{array}{c}\text { Last } \\
\text { infection } \\
\text { produced } \\
\text { by aphids } \\
\text { hour }\end{array}$} \\
\hline & & 1st & $2 \mathrm{~d}$ & $3 \mathrm{~d}$ & 4 th & 5 th & 6 th & \\
\hline \multicolumn{9}{|l|}{ Cabbage aphid, Brevicoryne brassicae } \\
\hline 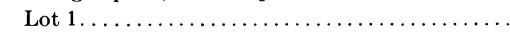 & 20 & + & + & + & - & - & - & $3 d$ \\
\hline 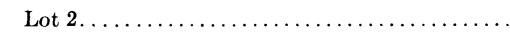 & 20 & + & + & - & - & - & - & $2 d$ \\
\hline 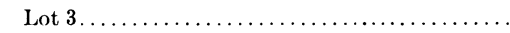 & 20 & + & + & - & - & - & - & $2 \mathrm{~d}$ \\
\hline 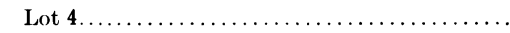 & 20 & + & - & - & - & - & - & 1st \\
\hline 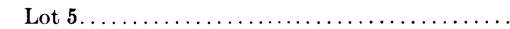 & 20 & + & - & - & - & - & - & 1st \\
\hline \multicolumn{9}{|l|}{ Turnip aphid, Rhopalosiphum pseudobrassicae } \\
\hline 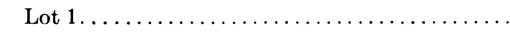 & 20 & + & + & + & - & - & - & $3 d$ \\
\hline Lot $2 \ldots \quad \ldots \ldots \ldots \ldots \ldots \ldots$ & 20 & + & + & - & - & - & - & $2 \mathrm{~d}$ \\
\hline Lot $3 \ldots \ldots \ldots$ & 20 & + & + & - & - & - & - & $2 \mathrm{~d}$ \\
\hline Lot 4 & 20 & + & + & - & - & - & - & $2 \mathrm{~d}$ \\
\hline Lot $5 \ldots \ldots \ldots \ldots \ldots \ldots \ldots$ & 20 & + & + & - & - & - & - & $2 \mathrm{~d}$ \\
\hline \multicolumn{9}{|l|}{ Ornate aphid, Myzus ornatus } \\
\hline Lot $1 \ldots \ldots \ldots \ldots \ldots \ldots \ldots$ & 20 & + & + & - & - & - & - & $2 d$ \\
\hline Lot $2 \ldots \ldots \ldots \ldots \ldots \ldots \ldots \ldots \ldots \ldots \ldots$ & 20 & + & + & - & - & - & - & $2 \mathrm{~d}$ \\
\hline Lot $3 \ldots \ldots \ldots \ldots \ldots \ldots \ldots \ldots \ldots \ldots$ & 20 & + & - & - & - & - & - & 1st \\
\hline $\operatorname{Lot} 4 \ldots \ldots \ldots \ldots \ldots \ldots \ldots$ & 20 & + & - & - & - & - & - & 1 st \\
\hline Lot $5 \ldots \ldots \ldots \ldots \ldots \ldots \ldots \ldots \ldots \ldots$ & 20 & + & - & - & - & - & - & 1 st \\
\hline \multicolumn{9}{|l|}{ Green peach aphid, Myzus persicae } \\
\hline Lot $1 \ldots \ldots \ldots \ldots \ldots \ldots \ldots \ldots \ldots$ & 20 & + & - & - & - & - & - & 1st \\
\hline 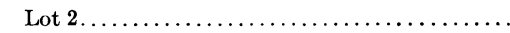 & 20 & + & - & - & - & - & - & 1 st \\
\hline Lot $3 \ldots \ldots \ldots \ldots \ldots \ldots \ldots \ldots \ldots \ldots \ldots \ldots \ldots \ldots \ldots \ldots$ & 20 & + & - & - & - & - & - & 1st \\
\hline 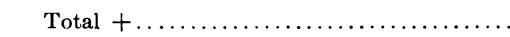 & .. & 18 & 10 & 2 & 0 & 0 & 0 & \\
\hline 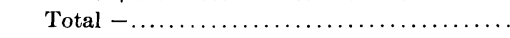 & .. & 0 & 8 & 16 & 18 & 18 & 18 & \\
\hline
\end{tabular}

* The plus sign $(+)$ indicates the production of the disease, and the minus $(-)$ shows that no disease resulted.

\section{SUMMARY}

The symptoms of radish mosaic are described on experimentally infected plants. Four species of aphids which multiply on radish under natural conditions are vectors of the virus. These are:

Cabbage aphid, Brevicoryne brassicae (L.)

Turnip or false cabbage aphid, Rhopalosiphum pseudobrassicae (Davis)

Ornate aphid, Myzus ornatus Laing

Green peach aphid, Myzus persicae (Sulzer)

The following eight species of aphids which do not multiply on radish in the greenhouse are vectors of the virus:

Celery aphid, Aphis apii Theobald

Rusty-banded aphid, Aphis ferruginea-striata Essig

Cotton or melon aphid, Aphis gossypii Glover

Bean or dock aphid, Aphis rumicis $\mathrm{L}$.

Yellow willow aphid, Cavariella aegopodii (Fabricius)

Pea aphid, Macrosiphum pisi (Kaltenbach)

Lily aphid, Myzus circumflexus (Buckton)

Foxglove aphid, Myzus solani (Kaltenbach) 
Higher percentages of transmission of the virus were obtained with previously noninfective, starved aphids in short infection-feeding intervals than with unstarved, infective aphids, with the exception of the bean or dock, cabbage, yellow willow, and pea aphids.

Mechanical inoculation (68 per cent) was more efficient than transmission of the virus by 11 species of aphids ( 54 per cent).

In tests on retention of the virus with four species of aphids, 20 in each lot, all species transmitted the virus during the first day, but none of the lots produced infections during the second and third days.

In tests with hourly transfers, transmissions occurred within the first three hours after the aphids had fed on a mosaic-infected plant.

The radish-mosaic virus is a nonpersistent type in the aphid vectors.

DALE, W. T.

\section{LITERATURE CITED}

1948. Observations on a virus disease of certain crucifers in Trinidad. Ann. Appl. Biology $35(4): 598-604$.

Magistad, O. C.

1938. Daikon (Raphanus sp.) mosaic. Hawaiian Agr. Exp. Sta. Rept. 4074:1-117.

PARRIS, G. K.

1940. A check list of fungi, bacteria, nematodes, and viruses occurring in Hawaii, and their hosts. The Plant Disease Reporter Suppl. 121:1-121.

Tompkins, C. M.

1936. Studies on the effect of carborundum as an abrasive in plant virus inoculations. Phytopathology 25(6):578-87.

1939. A mosaic disease of radish in California. Jour. Agr. Res. 58(2) :119-130.

WATSON, M. A.

1940. Studies on the transmission of sugar-beet yellows virus by the aphis, Myzus persicae (Sulz.). Roy. Soc. London Proc. Ser. B. 128:535-52.

Watson, M. A., and F. M. RoberTs.

1940. Evidence against the hypothesis that certain plant viruses are transmitted mechanically by aphids. Ann. Appl. Biol. 27:227-33. 


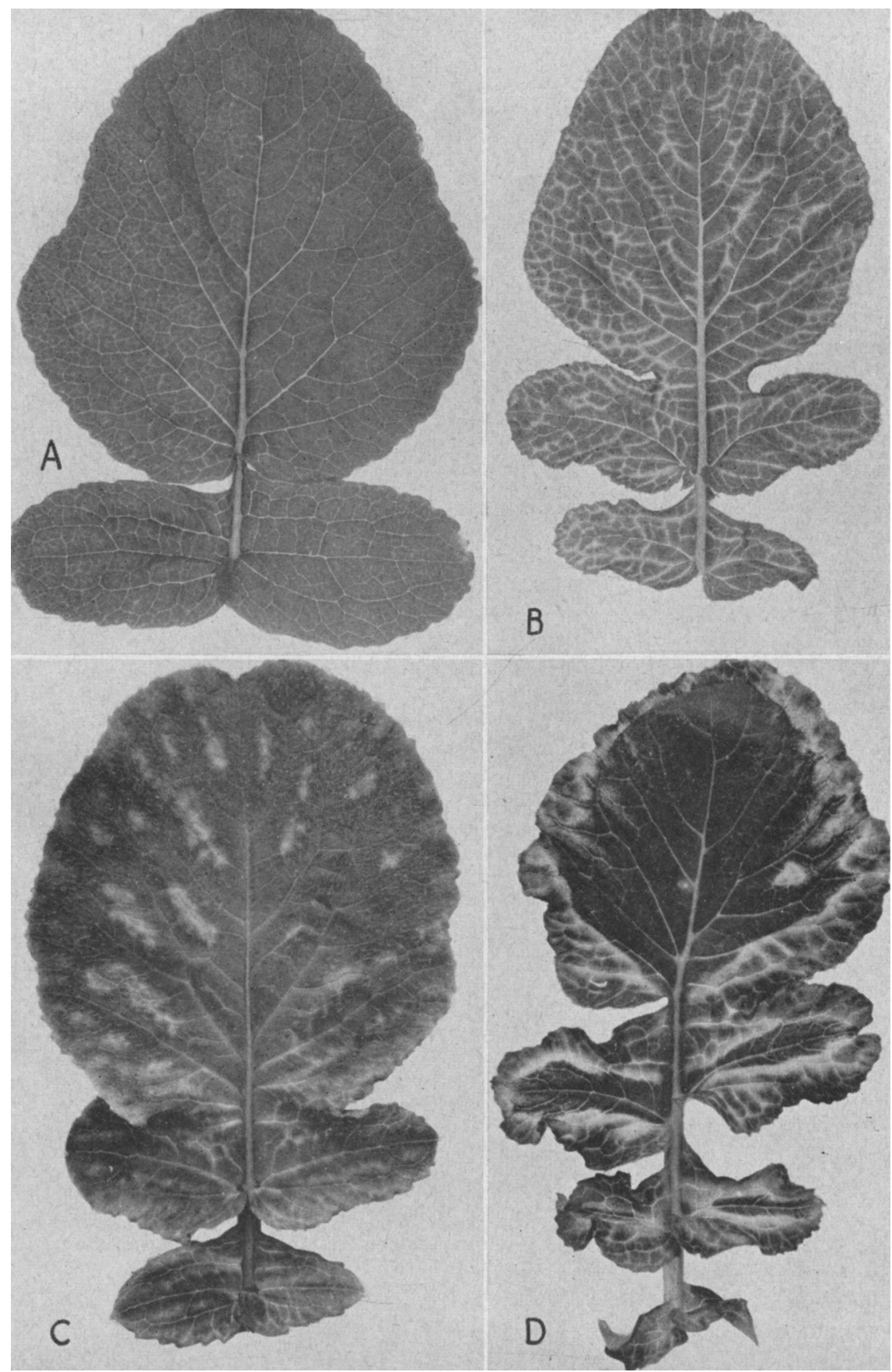

Plate 1. Symptoms of mosaic on leaves of White Icicle radish (Raphanus sativus): $A$, cleared veins and veinlets; $B$, yellow veinbanding of clear veins and veinlets; $C$, chlorotic veinbanding; $D$, marginal chlorosis. 


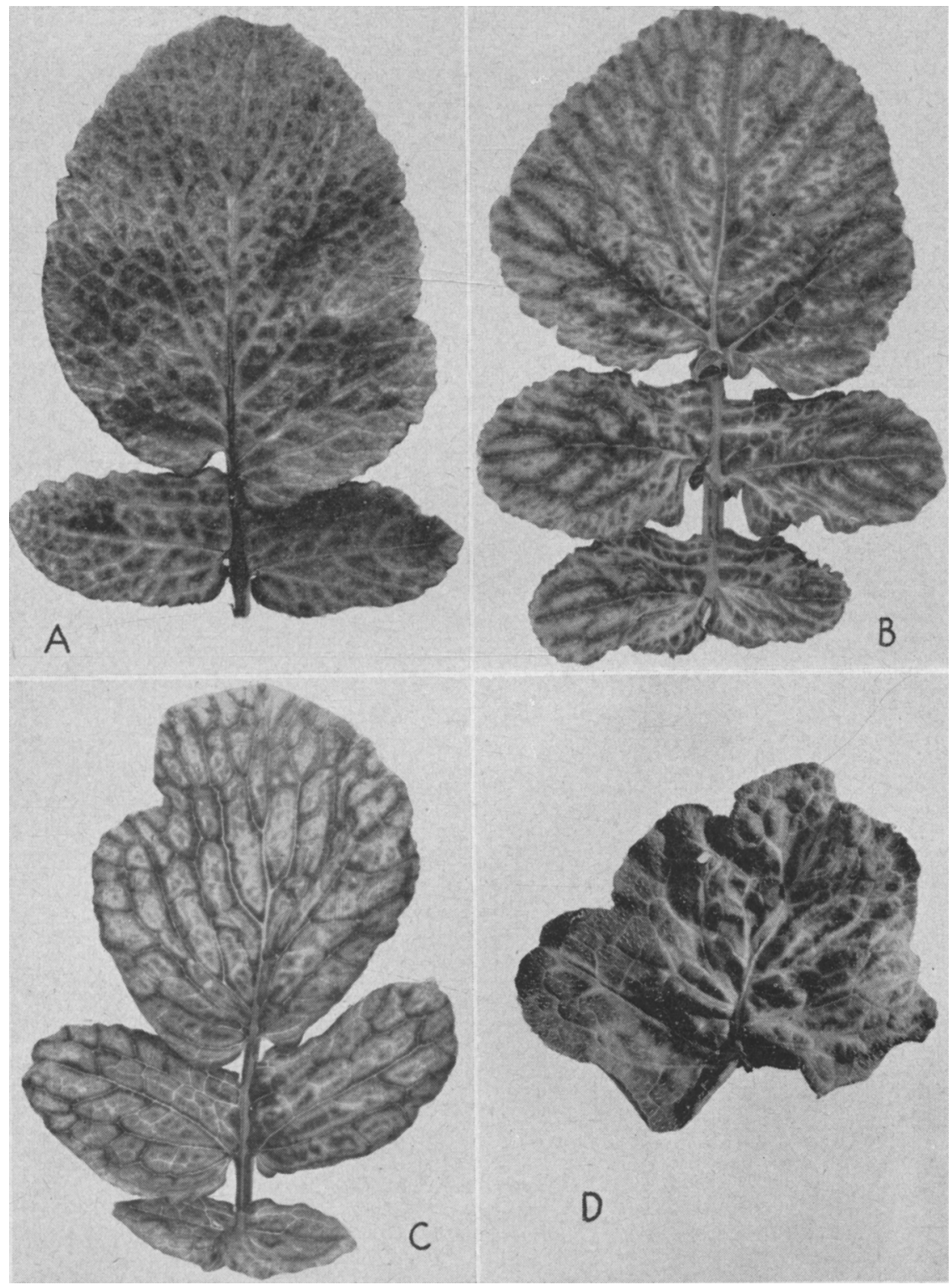

Plate 2. Symptoms of mosaic on leaves of White Icicle radish (Raphanus sativus): $A, B, C$, successive stages of yellow veinbanding enclosing slight raised green areas; $D$, blisterlike elevations. 

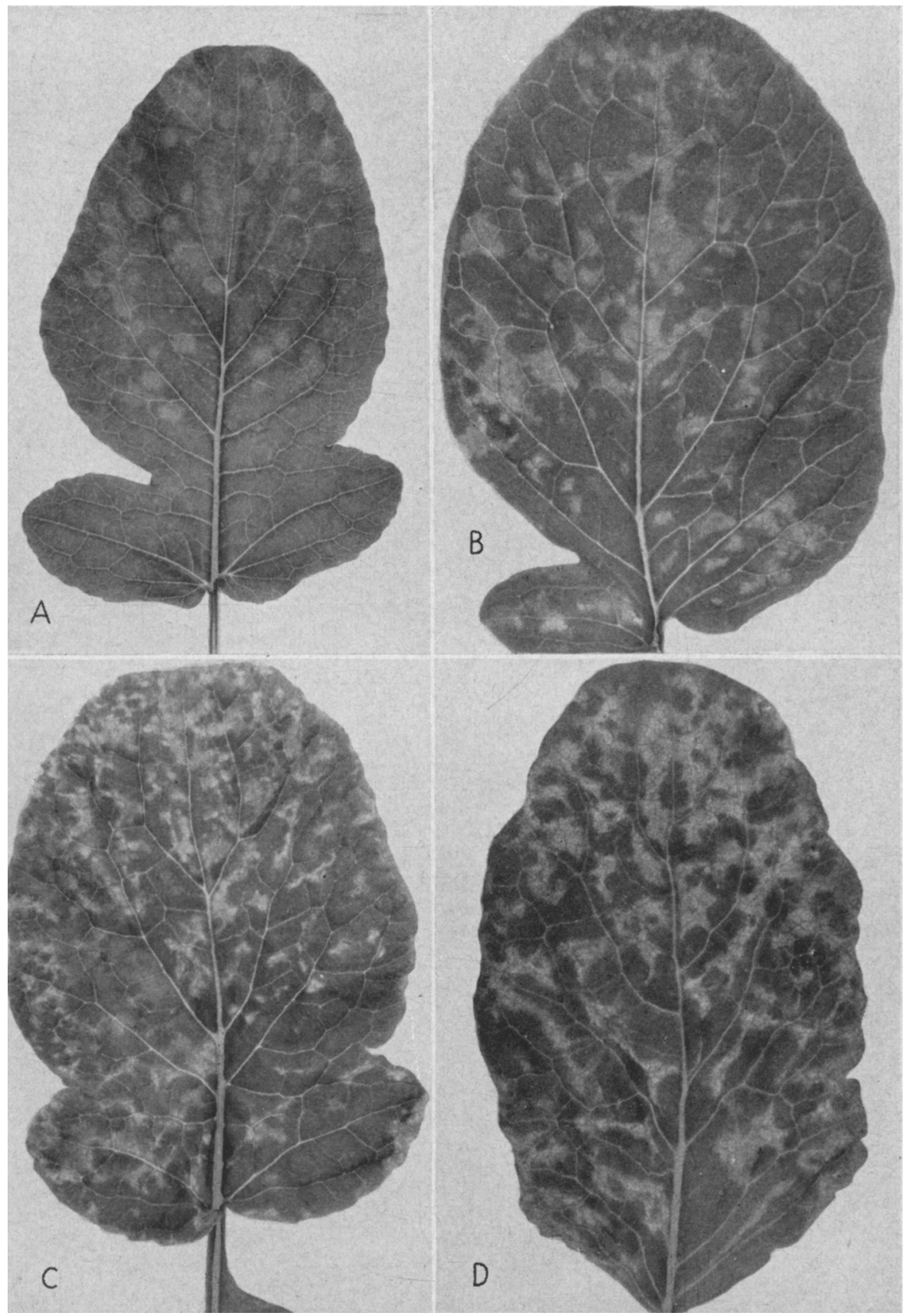

Plate 3. Symptoms of mosaic on leaves of White Icicle radish (Raphanus sativus): A, circular, chlorotic areas between and adjacent to the veins; $B$, fusion of chlorotic areas; $C, D$, numerous fused chlorotic areas, replacing the normal green tissue with a coarse mottle. 


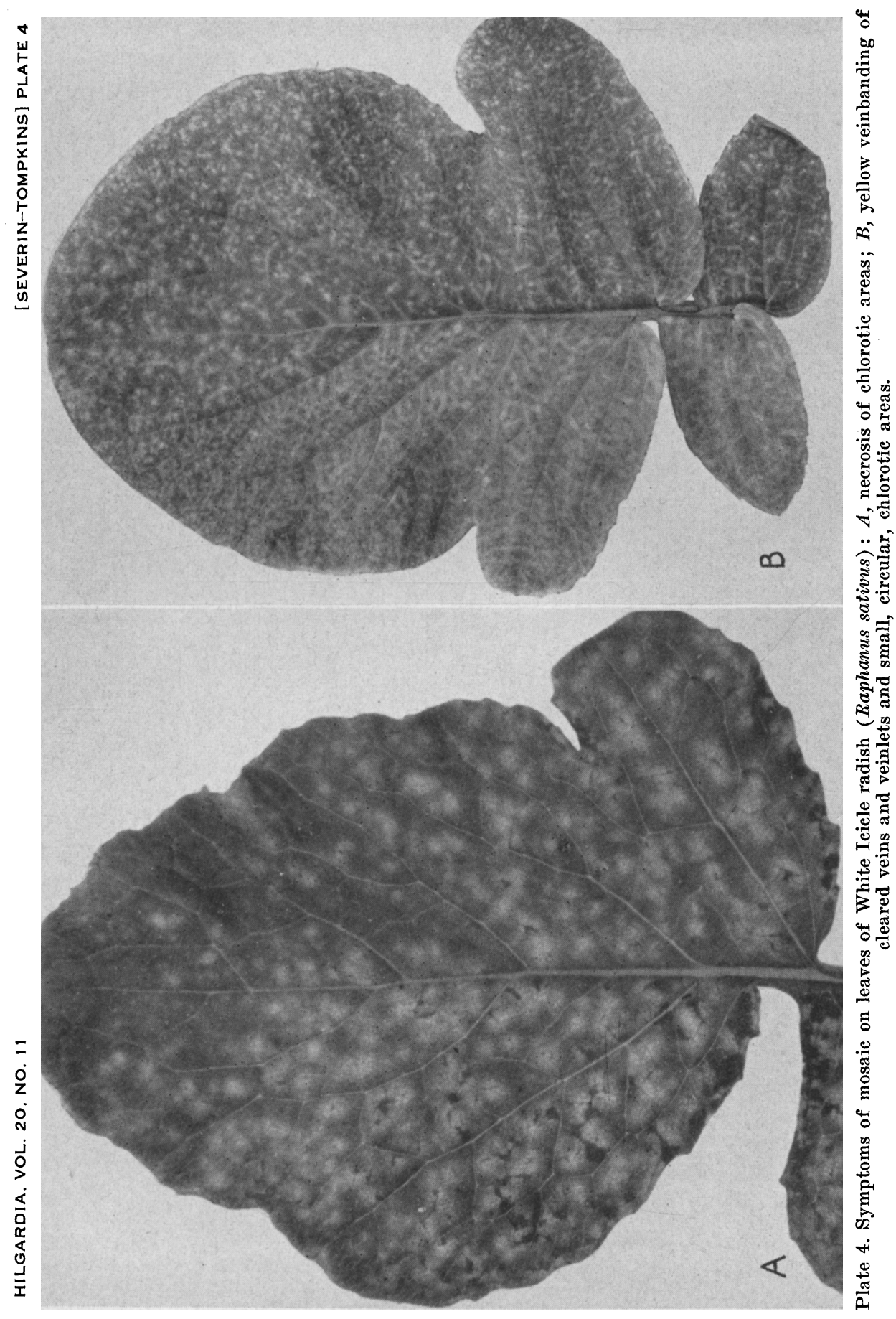



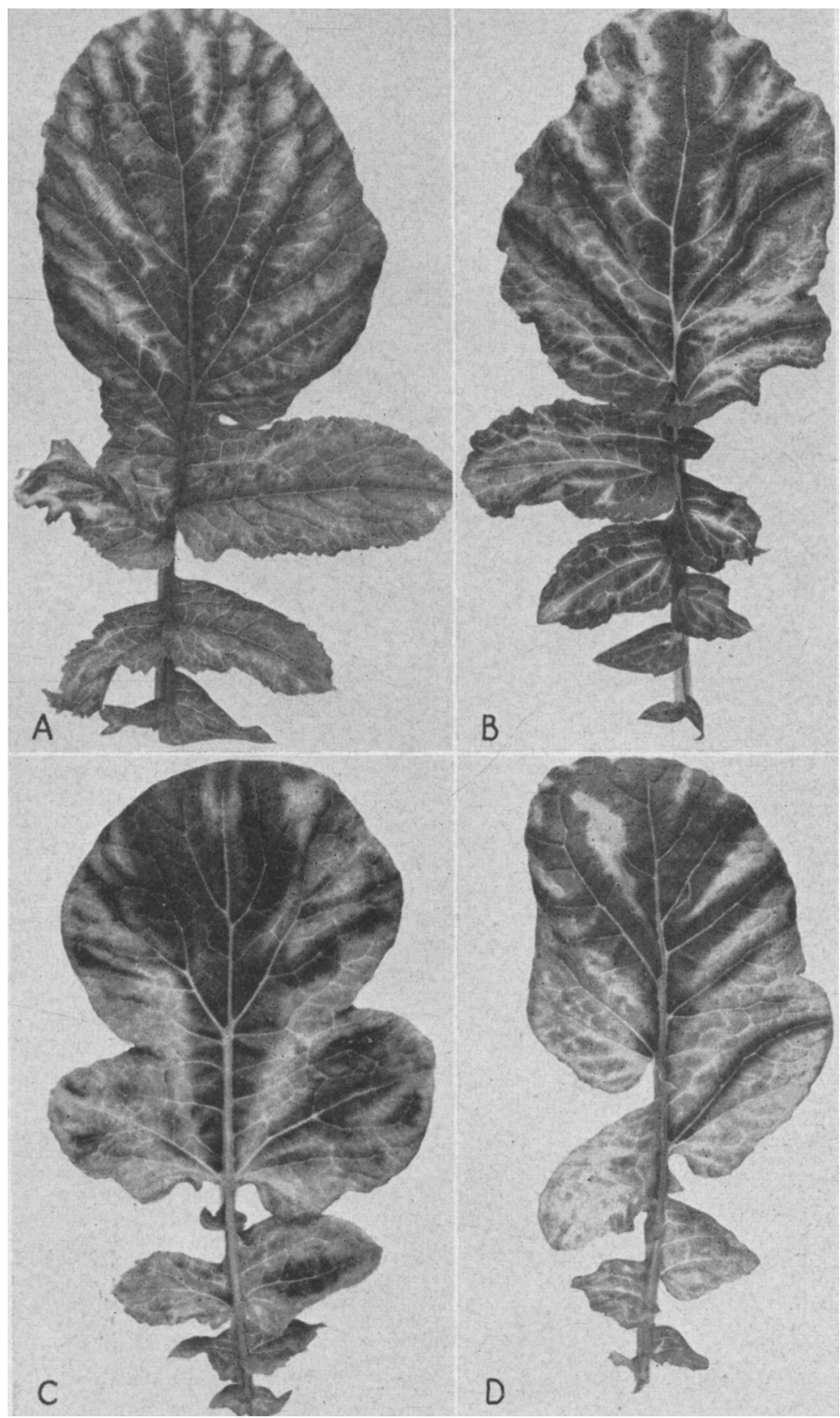

Plate 5. Symptoms of mosaic on leaves of White Icicle radish (Raphanus sativus) : $A, B$, interveinal chlorosis; $C, D$, chlorosis spreading until leaves become yellow. 


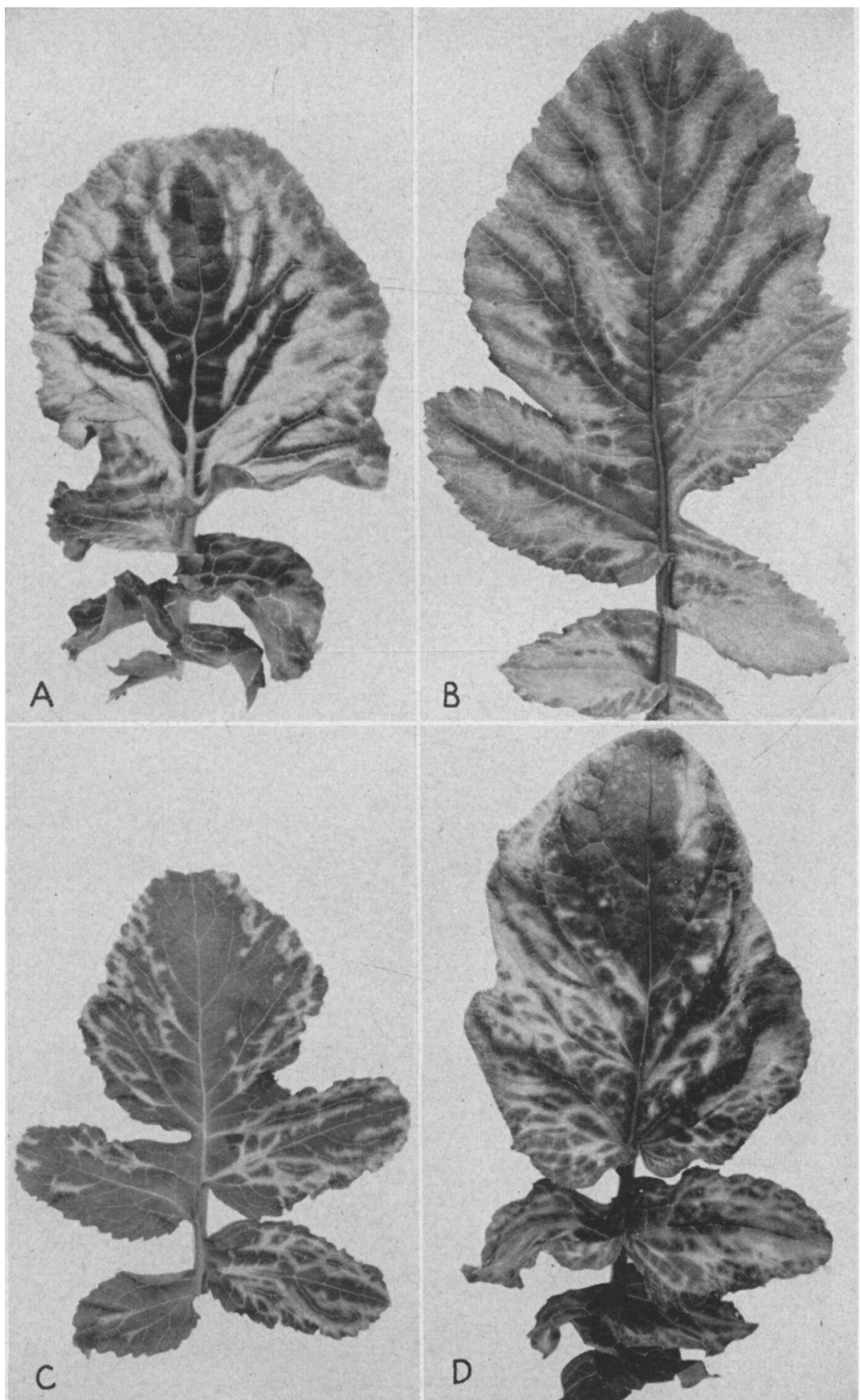

Plate 6. Symptoms of mosaic on leaves of White Icicle radish (Raphanus sativus ): $A, B$, green veinbanding; $C$, chlorotic veinbanding; $D$, blisterlike elevations. 


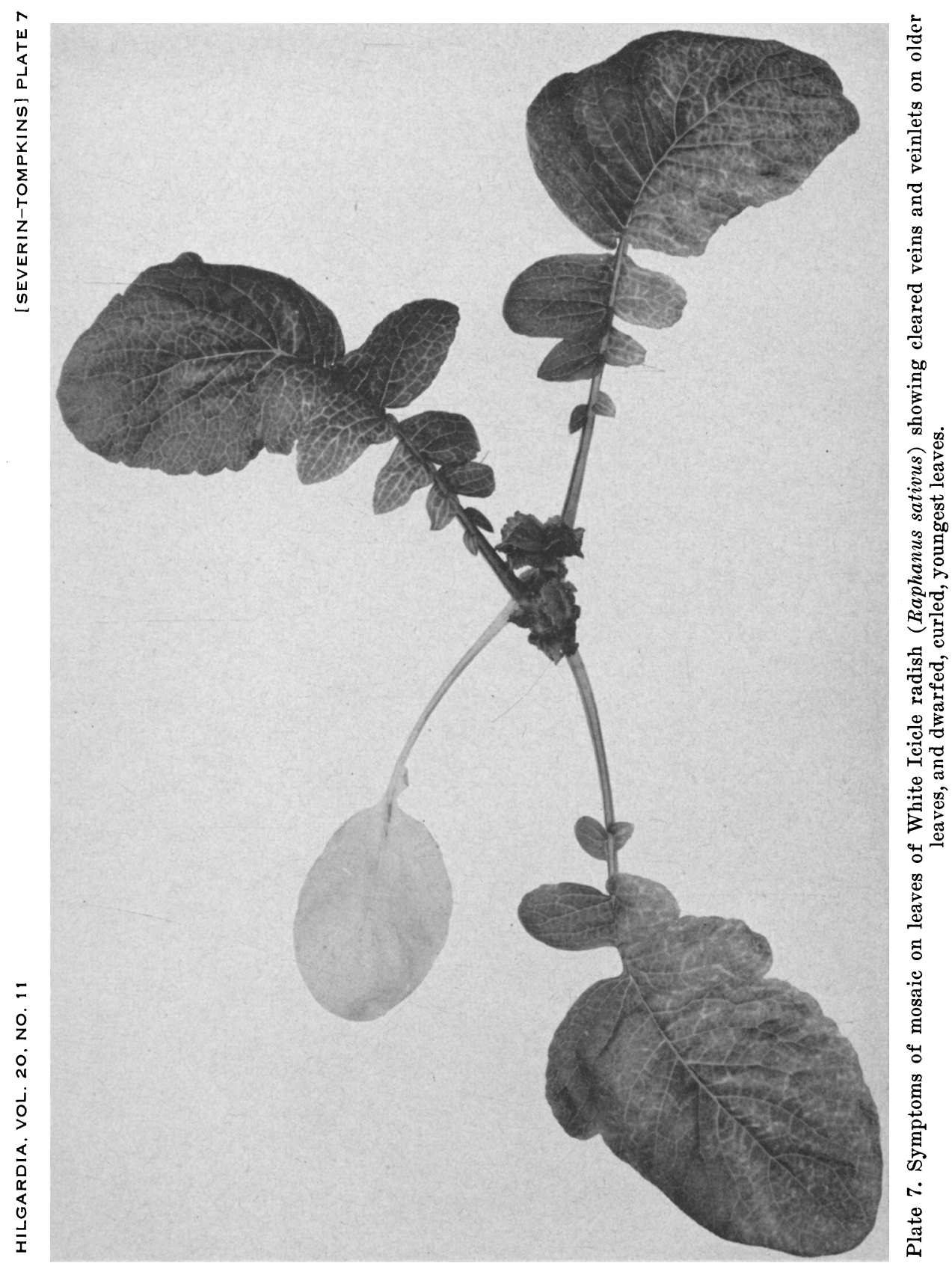



The journal Hilgardia is published at irregular intervals, in volumes of about 600 pages. The number of issues per volume varies. Subscriptions are not sold. The periodical is sent as published only to libraries, or to institutions in foreign countries having publications to offer in exchange.

You may obtain a single copy of any issue free, as long as the supply lasts; please request by volume and issue number from:

\section{Publications Office \\ College of Agriculture \\ Berkeley 4, California}

The limit to nonresidents of California is 10 separate issues on a single order. A list of the issues still available will be sent on request. 